Author version: J. Mar. Syst.: 77(1-2); 2009; 137-147

\title{
Seasonal and spatial distribution of particulate organic matter in the Bay of Bengal
}

\author{
Loreta Fernandes ${ }^{\text {a, }}$, Narayan B. Bhosle ${ }^{\text {a }}$, S. G. Prabhu Matondkar ${ }^{\text {a }}$, Ravi Bhushan ${ }^{\text {b }}$ \\ ${ }^{a}$ National Institute of Oceanography ( Council of scientific and Industrial Research), Dona Paula - \\ 403004, Goa, India. \\ ${ }^{\mathrm{b}}$ Physical Research Laboratory, Ahmedabad, India. \\ *Corresponding author: email: loreta@ nio.org; loretaferns@gmail.com \\ Tel.:+91 8232450537 ; Fax: +91 8322450602.
}

\begin{abstract}
In this paper, we have assessed the temporal, spatial and depth related variation of suspended particulate organic matter (POM) in the Bay of Bengal. For this purpose, suspended particulate matter (SPM) samples were collected from eight depths (2 to $1000 \mathrm{~m}$ ) at 9 locations in the Bay of Bengal during July/August 2001 (Southwest monsoon, SWM), September/October 2002 (Fall Intermonsoon, FIM), and March/April 2003 (Spring Inter-monsoon, SPIM). The SPM samples were analyzed for chlorophyll a $(\mathrm{Chl} a)$, particulate organic carbon (POC) and total particulate nitrogen (TPN). The surface concentrations of POC varied from 4.3 to $11.1 \mu \mathrm{M} \mathrm{C}, 3.1$ to $10.9 \mu \mathrm{M}$ C, and 4.3 to $9.0 \mu \mathrm{M}$ C during SWM, FIM, and SPIM, respectively. The levels of SPM, and the concentrations of $\mathrm{Chl} \mathrm{a}$, and POC were relatively higher in the offshore compared to the near shore stations, especially during SWM. The POC concentration and its contribution to the SPM were higher in the surface waters, and both decreased with increasing water column depth at most of the stations. The observed decrease with depth of POC indicates heterotrophic uptake and/or dilution by inorganic material, poor in POC. This was also reflected in the $\mathrm{C} / \mathrm{N}$ ratio which generally increased with water column depth. The relatively low $\mathrm{C} / \mathrm{N}$ and $\mathrm{POC} / \mathrm{Chl}$ a ratios, and high $\mathrm{Chl}$ a and \% POC during the SWM and FIM indicate the presence of relatively fresh POM in the Bay during these two seasons. The observed seasonal differences in the quality of POM appears to be governed by river run-off and the physical forces such as eddies which pump nutrients into the surface waters thereby enhancing biological production.
\end{abstract}

Keywords: Suspended particulate matter; Particulate organic carbon; $\mathrm{C} / \mathrm{N}$ ratios; Seasonal variations; Bay of Bengal. 


\section{Introduction}

In deep oceanic environments, particulate organic matter (POM) is mostly produced by phytoplankton using the process of photosynthesis. However, in the coastal and shelf environments, POM is derived from many sources including phytoplankton, terrestrial material, river run-off, resuspension of sediments, and aeolian inputs (Degens and Ittekkot, 1985). Quality and quantity of the POM produced by phytoplankton depend on nutrient status of the natural waters, phase of growth and phytoplankton composition. POM is of considerable biogeochemical and oceanographic importance in the aquatic environment. For example, it serves as a useful vehicle for the transport of organic matter produced in the upper euphotic zone of the ocean to the deep-sea sediments. As the POM is transported to greater depths, it is degraded by the in- situ heterotrophic organisms (Lee and Wakeham, 1988; Grossart and Ploug, 2001). As the POM is degraded, nutrients are released in deep waters making them nutrient rich (Eppley and Peterson, 1979). Therefore, understanding the distribution of particulate organic carbon (POC), total particulate nitrogen (TPN) and the contribution of these compounds to suspended particulate matter (SPM) provides useful information on the dynamics, nature, sources, and fate of POM.

There are many studies on the distribution of POC in the Pacific and Atlantic Ocean (Romankevich, 1984; Gordon and Cranford 1985; Yoro et al., 1997). However, little information is available on the distribution of POC (Bhosle et al., 1988) in the Indian Ocean in general, and in the Bay of Bengal in particular (Radhakrishna et al.,1978; Bhattathiri et al., 1980; Nandakumar et al., 1987). Bay of Bengal receives large influx of fresh water that decreases the sea-surface salinity. Moreover, the presence of weak winds $\left(<10 \mathrm{~m} \mathrm{~s}^{-1}\right)$ and warm sea-surface temperature $\left(>28{ }^{0} \mathrm{C}\right)$ results in strong stratification of the mixed layer. As a result, low or no nutrients are injected into the surface waters thereby, influencing biological production (Prasanna Kumar et al., 2007). However, it is not known how these physical and chemical parameters influenced the quality and the quantity of POM in the Bay. Therefore, the aim of this research is, 1) to assess the seasonal, spatial and depth related variation in SPM, Chl a, POC and TPN, and 2) to evaluate the factors that influenced the distribution and cycling of these compounds in the Bay of Bengal.

\section{Materials andethods}

\subsection{Study area}

The Bay of Bengal is one of the largest fresh water input sites of the world ocean. The annual fresh water discharge into the Bay exceeds $1.625 \times 10^{12} \mathrm{~m}^{-3} \mathrm{yr}^{-1}$. Because of the freshwater, the mean salinity of the waters reduces by about 7 psu in the northernmost region. The input of the fresh water into the Bay is mainly through the Himalayan rivers - the Ganga and Brahmaputra, 
Mahanadi in the north, Godavari and Krishna in the central region, and Irrawady, Penner and Cavery in south (Rao, 1985). About, $0.6 \times 10^{12} \mathrm{~mol} \mathrm{C}_{\text {org }} \mathrm{yr}^{-1}$ is brought into the Bay by the GangaBrahmaputra system (Galy et al., 2007). The warm sea surface temperature (SST's) and the low salinity in the Bay of Bengal lead to strong stratification of the water column, which prevents the transport of nutrient rich bottom waters into the surface. Moreover, the weak winds prevailing in the Bay of Bengal are unable to break the thermocline layer. Prasanna Kumar et al. $(2004,2007)$ proposed the role of cold core eddies in pumping nutrients in the surface waters and enhancing biological productivity of the Bay of Bengal. Some localized upwelling has also been observed along the south western boundary of the Bay (Shetye et al., 1991).

\subsection{Collection of samples}

The samples were collected from many locations during various cruises of ORV Sagar Kanya in the Bay of Bengal. The first cruise was during southwest summer monsoon (SWM) from 6 July to 2 August 2001, second in fall inter-monsoon (FIM) from 14 September to 12 October 2002, and the third in spring inter-monsoon (SPIM) from 9 April to 13 May 2003. During these cruises, seawater samples were collected using $30 \mathrm{~L}$ Niskin bottles attached to the CTD rosette system from 8 discrete depths (2 to $1000 \mathrm{~m}$ ) at 5 offshore stations along $88^{\circ} \mathrm{E}$ and 4 near shore stations along western boundary (Fig.1). Immediately after collection, water samples were passed through $200-\mu \mathrm{m}$ nylon screen to remove the zooplankton. Samples were then filtered onto pre-weighed and preashed GF/F filters (47 mm, $0.7 \mu \mathrm{m}$ pore size) for the analysis of the suspended particulate matter (SPM), chlorophyll a ( $\mathrm{Chl}$ a), particulate organic carbon (POC) and total particulate nitrogen (TPN). After collection, SPM samples were thoroughly washed with Milli-Q purified water and dried at 50 ${ }^{\circ} \mathrm{C}$. All the samples, except $\mathrm{Chl} a$, were transferred to clean vials and stored at $4{ }^{\circ} \mathrm{C}$.

\subsection{Analytical methods}

The SPM retained on the GF/F glass filters were dried at $50{ }^{\circ} \mathrm{C}$ in an oven, cooled in a dessicator, and weighed on the micro balance (Mettler Model AT20) so as to determined SPM content. Immediately after collection, $\mathrm{Chl}$ a was extracted by overnight incubation (in the dark at 4 ${ }^{\circ} \mathrm{C}$ ) with $90 \%$ acetone, and was estimated following the spectrofluorometric method (Parson et al., 1984).

The GF/F filters for the analysis of POC and TPN were pre-treated overnight with $\mathrm{HCl}$ fumes to remove the inorganic carbon (Ferrari et al., 2003), and dried at $50{ }^{\circ} \mathrm{C}$. Samples were then packed in the aluminum foil and analyzed using Perkin Elmer, Elemental analyzer (Model -2400 CHN). The precision of the methods was better than $7 \%$. 


\subsection{Statistical analysis}

A simple regression analysis was done to assess the relationship of POC with TPN and Chl a using the excel program. Two way analysis of variance (ANOVA) was carried out to evaluate if the observed spatial, seasonal and depth related variation were significant or not in the SPM of Bay of Bengal.

\section{Results}

\subsection{General hydrography and biogeochemical patterns}

As part of Bay of Bengal process studies, a number of physical, chemical, and biological parameters were monitored. These results are published elsewhere (e.g. Madhupratap et al., 2003; Prasanna Kumar et al., 2004; Gauns et al., 2005; Sardessai et al., 2007). These results are briefly described here. During the SWM, the sea surface temperature (SST), varied from $28.4{ }^{\circ} \mathrm{C}$ to 29.0 ${ }^{\circ} \mathrm{C}$, and generally decreased from south towards north in the offshore transect along the $88{ }^{\circ} \mathrm{E}$. A similar south to north decrease in SST was observed during SPIM, except that the SST was slightly higher, varying from $30.5^{\circ} \mathrm{C}$ to $29.3^{\circ} \mathrm{C}$. In contrast, during FIM, temperature increased from south to north along $88^{\circ} \mathrm{E}$. For the near shore stations, along the western boundary SST decreased from south to north during SWM, FIM, and SPIM (Prasanna Kumar et al., 2004; Kumar et al., 2004a, b). At all the stations the water temperature decreased with the increasing sampling depth.

The surface salinity for the offshore stations varied from 28.1 to 34.6, and for the near shore stations it varied from 20.7 to 34.0 , during SWM, FIM, and SPIM, respectively. A south to north decrease in surface salinity for all the offshore and near shore stations was observed during the three sampling periods. A strong stratification was observed during SWM and FIM, while the water column was relatively less stratified in the SPIM.

During each of the sampling period, upheaval of water was noticed. This indicated the presence of cold core eddies in the study area. Nutrients, especially nitrate, was devoid in the upper $30 \mathrm{~m}$ of water column during SWM and FIM seasons; while during SPIM, $0.2 \mu \mathrm{M}$ of nitrate was detected (Sardessai et al., 2007). Column-integrated primary productivity (PP) along the offshore region, varied from 90 to 220,182 to 513 , and 203 to $427 \mathrm{mg} \mathrm{C} \mathrm{m}^{-2} \mathrm{~d}^{-1}$, while for the near shore region, it varied from 328 to 520, 196 to 350 and 305 to $438 \mathrm{mg} \mathrm{C} \mathrm{m}^{-2} \mathrm{~d}^{-1}$ during SWM, FIM and SPIM, respectively (Guans et al., 2005, Prasanna Kumar et al., 2007).

\section{2. $S P M$}

The SPM content increased from south to north, especially during SWM and FIM periods (Fig. 2 a-c), and at station 12, SPM content was highest during both, SWM (12 mg $\left.{ }^{-1}\right)$ and FIM (4.6 
$\mathrm{mg} / \mathrm{l})$. Conversely, for the stations along the western boundary no particular trend was recorded for the SPM (Fig. 2 d-f). Interestingly, shelf to slope transport of SPM was noticed at a few depths during FIM and SPIM (Fig. 2 g-i).

\section{3. $\mathrm{Chl} \mathrm{a}$}

As compared to the SPIM, concentrations of Chl a were higher in SWM and FIM, and increased from south to north for the stations in the offshore and the near shore region (Fig. 3). A sub-surface $\mathrm{Chl}$ a maxima at 30 to $60 \mathrm{~m}$ was always evident for most of the stations. A shelf to slope transport was evident at $30 \mathrm{~m}$ and $60 \mathrm{~m}$ in the FIM and the SWM, respectively (Fig. $3 \mathrm{~g}, \mathrm{~h}$ ). Seasonal variations in $\mathrm{Chl}$ a were highly significant $(\mathrm{F}=13.25, \mathrm{P}<0.001)$ for the offshore stations, while they were insignificant for the near shore stations $(F=2.88, P=0.1)$ (Table1). Depth related differences in Chl a were significant for FIM (for both offshore and near shore stations) and SPIM (offshore stations). Significant spatial differences were observed for the offshore stations in SPIM (Table 1).

\subsection{POC and \% POC}

In the Bay of Bengal, the surface POC concentrations ranged from 4.3 to $11.1 \mu \mathrm{MC}, 3.1$ to $10.9 \mu \mathrm{MC}$, and 4.3 to $9.0 \mu \mathrm{MC}$ in the SWM, FIM, and SPIM, respectively (Fig. 4). For both, the offshore and near shore stations, concentrations of POC showed some increase towards the northern area of the Bay of Bengal, especially in SWM and FIM. For all the seasons, POC concentrations were higher in the surface waters, and decreased from surface downwards at most of the stations. However, during the SWM, at a few stations $(03,06,09,12$, and 14) concentrations of the POC at $1000 \mathrm{~m}$ were either higher or similar to those recorded in the surface waters. Interestingly, in SWM, the POC concentration did not vary much from surface to $1000 \mathrm{~m}$ at station 9. During SWM, a shelf to slope transport of POC was observed (Fig. 4g).

A highly significant positive relationship was obtained between POC and TPN, during SWM $(r=0.9163, n=62, P>0.001), F I M(r=0.8551, n=70, P>0.001)$, and SPIM $(r=0.8831, n=69, P>$ 0.001), indicating a common source for these compounds in the Bay (Fig. 5a). Chl a showed a fairly good significant positive co-relationship with POC (SWM, $r=0.3656, P<0.02$; FIM, $r=0.4951, P>$ 0.001, and SPIM, $r=0.4965, P>0.001$ ), and TPN (SWM, $r=0.4010, P<0.01 ; F I M, r=0.6669$, $\mathrm{P}>0.001$ and SPIM, $r=0.5696, \mathrm{P}>0.001$ ) (Fig. 5b). For the offshore stations, a significant difference in spatial distribution of POC was observed for SWM ( $F=34.5, P<0.001)$, FIM $(F=2.87, P=0.04)$, and SPIM ( $F=5.55, P=0.002)$, while for near shore stations only FIM showed a significant difference $(F=7.15, P=0.002)$ (Table 1$)$. For both, the near shore and offshore stations, depth-wise differences in POC were significant during FIM and SPIM $(F=6.41-12.9, P<0.001)$ (Table 1). 
The POC accounted for 0.7 to $21.7 \%, 0.8$ to $11.9 \%$, and 2.0 to $28.8 \%$ of the SPM, in the SWM, FIM, and SPIM, respectively (Fig. 6). Overall, highest \% POC was recorded for the SWM and FIM seasons. With exception of a few stations during SWM, \% POC decreased from surface downwards. It was interesting to note that as compared to the surface, relatively higher \% POC was observed at $1000 \mathrm{~m}$ at some stations (stations 03, 06, 09, 12, and 14). A shelf to slope increase in $\%$ POC was observed for $10 \mathrm{~m}$ during SWM (Fig. 6g).

\section{6. $\mathrm{C} / \mathrm{N}$ atomic ratio}

Throughout the water column, $\mathrm{C} / \mathrm{N}$ ratio varied from 8.5 to 26 (Fig. 7), and were relatively low during FIM and SWM, and high in SPIM. The ratio generally increased from surface downwards. Increase in $\mathrm{C} / \mathrm{N}$ ratio from shelf to slope was also observed at $30 \mathrm{~m}$ in $\mathrm{FIM}$, and at $10 \mathrm{~m}$ during SPIM (Fig. 7h, i).

\section{Discussion}

There were apparent seasonal and spatial differences in the distribution of Chl a, SPM, and POC in the Bay of Bengal. Generally, the SPM content was higher for the SWM, intermediate for the FIM and relatively low in SPIM. Further, SPM content was generally high at the northern stations and low at the southern stations. In the Bay of Bengal, the influence of the freshwater input is greater in the northern region and subsequently decreased towards the southern stations of the Bay (stations 3 and 6) (Gopalakrishna et al., 2002). This is because, the stations (12 and 14) in the northern Bay receives large quantities of freshwater $\left(1.625 \times 10^{12} \mathrm{~m}^{-3} \mathrm{yr}^{-1}\right)$ from the major rivers Ganges, Brahmaputra, Irrawady, Godavari, Krishna, Pennar and Cauvery (Rao, 1985; Subramanian, 1993). These rivers flowing through the Indian sub-continent, introduce $2.0 \times 10^{15} \mathrm{~g}$ of suspended particulate matter annually in the Bay, accounting for $15 \%$ of the contemporaneous global discharge of fluvial sediments into the world oceans. From the seasonal and spatial distribution trends of the SPM, it was evident that river input in the Bay played an important role in controlling the abundance of the SPM in the study area.

Concentrations of POC and Chl a were generally higher during SWM. The excess precipitation over evaporation as well as the river run- off freshens up the upper water layers of the Bay of Bengal, especially the northern region. Apart from freshening of the surface, the river discharge is expected to add nutrients to the upper layers and increase the biological productivity of the Bay. During SWM, the upper ocean is highly stratified. Moreover, the relatively weaker winds are unable to break the strong upper ocean stratification through the wind driven mixing. Prasanna Kumar et al. (2004) identified cold core eddies in the Bay of Bengal, and proposed eddy pumping as a possible mechanism of vertical transfer of nutrients across the halocline to the oligotrophic euphotic zone 
during SWM. This would induce rapid biological uptake, and in turn significantly enhance biological production. Organic matter production due to nutrient addition by eddy-pumping and the organic matter inputs from the rivers, may be responsible for the observed higher concentrations of POC and Chl a during the SWM.

In the northern Bay, during FIM some increase in nitrate and silicate was detected due to fresh water run-off (Sardessai et al., 2007; Prasanna Kumar et al., 2007). During this period four cyclonic eddies, two each along the $88^{\circ} \mathrm{E}$ and the western boundary were observed, respectively. The availability of nutrients and improved light condition due to low concentrations of SPM resulted in doubling of the integrated primary productivity $\left(184 \mathrm{mg} \mathrm{C} \mathrm{m}^{-2} \mathrm{~d}^{-1}\right.$ ) towards the northern region, while it was more than double (513 $\mathrm{mg} \mathrm{C} \mathrm{m}^{-2} \mathrm{~d}^{-1}$ ) in the southern region. This was well supported by the high concentrations of $\mathrm{POC}$ and $\mathrm{Chl} a$ in the southern region as compared with northern region of the offshore region. Interestingly, although nutrients were present at both northern and southern regions, the low concentration of $\mathrm{POC}$ and $\mathrm{Chl} a$ in the northern stations, may indicate the effect of light limitation as the SPM was five times higher in the northern locations as compared to the southern locations.

During SPIM, nitrate isoclines showed weaker physical forcing compared to SWM and FIM seasons. The period was characterized with very low concentration of SPM and Chl a, but even then POC concentrations were found to be comparably higher. The column productivity was found to be higher than that observed for SWM and FIM. It was evident that biological production was mainly enhanced due to eddy pumping in the Bay. However, it was interesting to note that during FIM, the POC and Chl a concentrations in the southern station 03 were higher by a factor of about 2 than that recorded at the northern station 14 along the $88^{\circ} \mathrm{E}$ (offshore transect). In contrast, along the western boundary, the northern station 16 had more POC and $\mathrm{Chl} a$ than that of the southern station 23. The low concentration of organic matter in north along the $88{ }^{\circ} \mathrm{E}$ transect, in spite of nutrient availability in the upper water column, points to the possibility of light limitation due to suspended sediment load brought in by the river run- off. Along the northern part of the near shore region, however, the quantity of nutrient in the surface waters is more than that in the northern part of the offshore transects (Sardessai et al., 2007). For SPIM a similar trend was recorded. However, during this season the organic matter production was entirely controlled by eddy pumping of nutrients (Prasanna Kumar et al., 2007).

POC concentrations in the present study are in the range of values reported from other oceanic regions (Gordon et al., 1979; Copin-Montegut and Copin-Montegut, 1983; Romankevich, 1984; Gordon and Cranford, 1985; Kucuksezgin et al., 2005). However, these POC concentrations are relatively lower than those reported earlier for the Bay (Radhakrishna et al., 1978; Bhattathiri et al., 1980; Nandakumar et al., 1987). A CHN analyzer was used in the present study, whereas, a 
spectrophotometeric method of Parson et al. (1984) was used in earlier studies to estimate POC (Radhakrishna et al., 1978; Bhattathiri et al., 1980; Nandakumar et al., 1987). This difference in the analytical methods was probably responsible for the observed differences in the POC concentrations.

The phytoplankton abundance played an important role in controlling the concentrations of POC and TPN. This was evident from the fairly good significant positive correlations of the concentrations of Chl a with the concentrations of POC and TPN (Fig. 5). This implies that the POC and TPN were mostly derived from phytoplankton, and were not influenced by terrestrial organic matter to a great extent.

POC and its contribution to SPM (i.e. \% POC) in the Bay of Bengal generally decreased with the increasing water column depth during the SWM, FIM, and SPIM, indicating the biological utilization and/or dilution by inorganic material during its transport to the greater depths. However, deviation from the above general distribution pattern was observed during SWM at $1000 \mathrm{~m}$. During SWM, POC concentrations and \% POC decreased in the upper $500 \mathrm{~m}$ of the water column, and then gradually increased again at $1000 \mathrm{~m}$. The increased concentration at $1000 \mathrm{~m}$ is relatively higher and/or similar than that recorded in the surface waters. In the Bay of Bengal, three water masses i.e. the Arabian Sea High Salinity water mass (surface to $100 \mathrm{~m}$ ), the Bay of Bengal sub-surface water mass (100 to $300 \mathrm{~m}$ ), and the Indian Equatorial Intermediate water mass (> $300 \mathrm{~m}$ ) have been identified (Gallagher, 1966; Sardessai et al., 2007). Therefore, the advection of the Indian Equatorial Intermediate water mass rich in the organic matter is probably responsible for the high concentrations of POC at $1000 \mathrm{~m}$. This organic matter was characterized with high \% POC and low $\mathrm{C} / \mathrm{N}$ ratio. This implies that the organic matter was relatively fresh and probably was produced by marine bacteria.

$\mathrm{C} / \mathrm{N}$ ratio is a useful tool to assess the nature of organic matter. The average $\mathrm{C} / \mathrm{N}$ ratio for the fresh living phytoplankton and bacteria is 7 and 4, respectively (Redfield et al., 1963; Lee and Furhman, 1987; Nelson and Robertson, 1993; Bale and Morris, 1998; Bates et al., 2005), while for the terrestrial organic matter, it varied from 20 to 200 (Hedges et al., 1986). During the period of study, the $\mathrm{C} / \mathrm{N}$ ratios varied with season, space, and depth. For most of the stations, the $\mathrm{C} / \mathrm{N}$ ratios were low (<9), especially during FIM and SWM, suggesting the presence of organic matter derived from phytoplankton. This conclusion was also supported by the significant correlation between POC and $\mathrm{Chl}$ a. However, at some offshore and near shore stations, particularly during SPIM, and near shore stations in SWM showed high (>9) $\mathrm{C} / \mathrm{N}$ ratios suggesting the presence of either the degraded organic matter or the influence of terrestrial organic matter. If, it was the latter then we would have expected higher concentrations of carbohydrates since terrestrial material is rich in cellulose. 
However, we did not observe high yields of carbohydrates at these stations indicating that the high $\mathrm{C} / \mathrm{N}$ ratios were due to the presence of degraded organic matter (Khodse et al., 2007).

\section{Conclusions}

In the Bay of Bengal Chl a, SPM, and POC varied spatially, depth wise and seasonally. In near surface waters, nutrients were brought in by the river run-off, and/or were also injected due to eddies during SWM and FIM. This enhanced the concentrations of $\mathrm{Chl}$ a and POC during these seasons. Good correlation between $\mathrm{Chl} a$ and POC suggest that the organic matter was mostly derived from phytoplankton. However, the biological production was relatively low in northern as compared to the southern stations probably because of light inhibition due to high SPM content in the former region. During the SPIM, river run-off was very poor or negligible and biological production was mostly controlled by eddies. Therefore, the observed high values of POC during this season may indicate the influence of eddies. The decrease in the concentrations of the POC from surface downwards indicates the utilization by the in situ organisms. This conclusion is also supported by the increasing trends recorded for the $\mathrm{C} / \mathrm{N}$ ratios. Our data on POM indicate that the river run-offs and cyclonic eddies played an important role in controlling the quality and quantity of POM in the Bay of Bengal.

\section{Acknowledgements}

The authors are grateful to Dr. Satish R. Shetye, the Director NIO for encouragement and facilities. We thank the Department of Ocean Development for financial support. We also appreciate the help rendered by Dr. Prasanna Kumar and the BOBPS team members on board Sagar Kanya. The authors also thank Ms. Jayu Narvekar and Mr. Suhas Shetye for their help. We are grateful to anonymous referees and the Co-Editor for critical but useful comments regarding the manuscript. This is NIO contribution no. 4435. 


\section{References}

Bale, A., Morris, A., 1998. Organic carbon in suspended particulate material in the North Sea: effect of mixing resuspended and background particles. Cont. Shelf Res. 18, $1333-1345$.

Bates, N. R., Dennis, A., Hansell, D. A., Moran, S. B., Codispoti, L. A., 2005. Seasonal and spatial distribution of particulate organic matter (POM) in the Chukchi and Beaufort Seas. Deep- Sea Res. II 52, 3324 - 3343.

Bhattathiri, P. M. A., Devassy, V. P., Radhakrishna, K.,1980. Primary production in the Bay of Bengal during southwest monsoon of 1978. Mahasagar-Bulletin of the National Institute of Oceanography 13, $315-323$.

Bhosle, N. B., Dhople, V. M., Wagh, A. B., 1988. Distribution of particulate organic carbon in the central Arabian Sea. Proc. Indian Acad. Sci. ( Earth Planet. Sci.) 97, 35 - 47.

Copin-Montegut, C., Copin-Montegut, G., 1983. Stoichiometry of carbon, nitrogen and phosphorus in marine particulate matter. Deep-Sea Res. 30, 31-46.

Degens, E.T., Ittekkot, V., 1985. Particulate organic carbon an overview. In: Degens, E.T., Kempe, S.K.and Herrera, R., (editor). Transport of Carbon and Minerals in Major World Rivers. Mitt. Geol. Palaont. Inst. Univ. Hamburg, 58, 7-27.

Eppley, R.W., Peterson, B.J., 1979. Particulate organic matter flux and panktonic new production in the deep ocean. Nature 282, 677-680.

Ferrari, G. M., Bo, F. G., Babin, M., 2003. Geo-chemical and optical characterization of suspended matter in European coastal waters. Est., Coast. and Shelf Sci. 57, 17 -24.

Gallagher, J. F., 1966. The Variability of Water Masses in the Indian Ocean. 74pp Washington DC: national Oceanographic Data Centre, 1966 (General Series, Publ. G-11).

Galy, V., Lanord, C.F., Beyssac, O., Faure, P., Kudrass, H., Palhol, F., 2007. Efficient organic carbon burial in the Bengal fan sustained by Himalayan erosional system. Nature 450, 407411. doi:10.10.1038/nature06273.

Gauns, M., Madhupratap, M., Ramaiah, N., Jyothibabu, R., Fernandes, V., Paul, J.T., Prasanna Kumar, S., 2005. Comparative accounts of biological productivity characteristics and estimates of carbon fluxes in the Arabian Sea and Bay of Bengal. Deep- Sea Res. II 52, 2003-2017.

Gopalakrishna, V. V., Murty, V.S.N., Sengupta, D., Shenoy, S., Araligidad, N., 2002. Upper ocean stratification and circulation in the northern Bay of Bengal during southwest monsoon of 1991. Cont. Shelf Res. 22, $791-802$.

Gordon, D. C., Wangersky, P. J., Sheldon, R. W., 1979. Detailed observations on the distribution and composition of particulate organic material at two stations in the Sargasso Sea. Deep-Sea Res. 26,1083-1092. 
Gordon, D. C. Jr., Cranford, P. J., 1985. Detailed distribution of dissolved and particulate organic matter in the Arctic Ocean and comparison with other oceanic regions. Deep Sea Res.32, 1221-1232.

Grossant, H.P., Ploug, H., 2001. Microbial degradation of organic carbon and nitrogen on diatom aggregates. Limnol. Oceanogr. 46, 267-277.

Hedges, J.I., Clark, W.A., Quay, P.D., Richey, J.E., Devol, A.H., Santos, U., De, M., 1986. Composition and fluxes of particulate organic material in the Amazon River. Limnol. Oceanogr. 31, 717-738.

Khodse V. B., Fernandes, L., Gopalkrishna, V. V., Bhosle,N. B., Fernandes,V., Matondkar, S. G. P., Bhushan, R., 2007. Distribution and seasonal variation of concentrations of particulate carbohydrates and uronic acids in the northern Indian Ocean. Mar. Chem. 103, 327 - 346.

Kucuksezgin, F., Kontas, A., Altay, O., Uluturhan E., 2005. Elemental composition of particulate matter and nutrient dynamics in the Izmir Bay (Eastern Aegean). J. Mar. Sys. 56, 67 - 84.

Kumar, S., Ramesh, R., Bhosle, N.B., Sardesai, S., Sheshshayee, M.S., 2004a. Natural isotopic composition of nitrogen in suspended particulate matter in the Bay of Bengal. Biogeosciences 1, 63-70.

Kumar, S., Ramesh, R., Sardesai, S., Sheshshayee, M.S., 2004b. High new production in the Bay of Bengal: possible causes and implications. Geophys. Res. Lett. 31, L18304. doi:10.1029/2004GL021005.

Lee, S., Furhman, J. D., 1987. Relationships between biovolume and biomass of naturally derived marine bacterioplankton. Applied Env. Microbiol. 1298 -1303.

Lee, C., Wakeham, S.G., 1988. Organic matter in seawater: biogeochemical processes. In: Riley, J.P. (Ed.), Chemical Oceanography, Vol. 9. Academic Press, New York, pp. 1-51.

Madhupratap, M., Gauns, M., Ramaiah, N., Prasanna Kumar, S.,Muraleedharan, P.M., de Sousa, S.N., Sardessai, S., Muraleedharan, U., 2003. Biogeochemistry of the Bay of Bengal: physical, chemical and primary productivity characteristics of the central and western Bay of Bengal during summer monsoon 2001. Deep Sea Res. II 50, 881-896.

Nandakumar, K., Venkat, K., Bhosle, N. B., 1987. Distribution of particulate organic carbon in the central Bay of Bengal. Proc. Indian Acad. Sci.( Earth Planet. Sci.) 96, 189 - 193.

Nelson, J. R., Robertson, C. Y., 1993. Detrital spectral absorption: Laboratory studies of visible light effects on phytodetritus absorption, bacterial spectral signal, and comparison to field measurements. J. Mar. Res. 51, 181-207.

Parsons, T. R., Maita, Y., Lalli, C. M., 1984. A Manual of Chemical and Biological Methods for Seawater Analysis. Oxford: Peragamon press.

Prasanna Kumar, S., Nuncio, M.; Narvekar, J.; Kumar, A.; Sardessai, S.; DeSousa, S.N.; Gauns, M.; Ramaiah, N.; Madhupratap, M. 2004. Are eddies nature's trigger to enhance biological productivity in the Bay of Bengal? Geophys. Res. Lett. 31, 5. doi:10.1029/2003G1019274. 
Prasanna Kumar, S., Nuncio, M.; Ramaiah, N.; Sardessai, S.; Narvekar, J.; Fernandes, V.; Paul, J.T. 2007. Eddy-mediated biological productivity in the Bay of Bengal during fall and spring intermonsoons. Deep-Sea Res. I, 54, 1619-1640.

Radhakrishna, K., Bhattathiri, P. M. A., Devassy, V. P., 1978. Primary productivity of the Bay of Bengal during August - September 1976. Indian J. Mar. Sci. 7, 94-98.

Rao, C. M., 1985. Distribution of suspended particulate matter in the waters of eastern continental margin of India. Indian Journal of Marine Science 14, 14 -19.

Redfield, A.C., Ketchum, B.H., Richards, F.A., 1963. The influence of organisms on the composition of sea water, In: The Sea, Vol. 2, edited by M.N. Hill, pp 26-77, Interscience, New York.

Romankevich, E.A., 1984. Geochemistry of Organic Matter in the Ocean. Springer-Verlag, Berlin.

Sardessai, S., Ramaiah, N., Kumar, P. S., De Sousa, S. N., 2007. Influence of environmental forcings on the seasonality of dissolved oxygen and nutrients in the Bay of Bengal. J. Mar. Res. 65, $301-316$.

Shetye, S. R., Shenoi, S. S. C., Gouveia, A. D., Michael, G. S., Sundar, D., Nampoothri, G., 1991. Wind-driven coastal upwelling along the western boundary of the Bay of Bengal during the southwest monsoon. Cont. Shelf Res. 11, 1397 - 1408.

Subramanian, V., 1993. Sediment load of Indian Rivers. Current Science 64, 928-930.

Yoro, S. C., Sempéré, R., Turley, C.M., Unanue, M.A., Durieu De Madron, X., Bianchi, M., 1997. Cross-slope variations of organic carbon and bacteria in the Gulf of Lions in relation to water dynamics (northwestern Mediterranean). Mar. Ecol. Prog. Ser. 161, 255 - 264. 


\section{Legend to Figure and table:}

Fig.1. Study area and location of sampling sites in the Bay of Bengal.

Fig.2. Distribution of suspended particulate matter (SPM mg/l) in the offshore $(a, b, c)$, near shore $(d, e, f)$ and Shelf/Slope $(g, h, i)$ regions during SWM, FIM and SPIM in the Bay of Bengal.

Fig.3. Distribution of chlorophyll a ( Chl a ng/l) in the offshore (a, b, c), near shore (d, e, f) and Shelf/Slope $(g, h, i)$ regions during SWM, FIM and SPIM in the Bay of Bengal.

Fig.4. Distribution of particulate organic carbon (POC $\mu \mathrm{M} \mathrm{C})$ in the offshore $(a, b, c)$, near shore (d, $e, f)$ and Shelf/Slope $(g, h, i)$ regions during SWM, FIM and SPIM in the Bay of Bengal.

Fig.5. Correlations between particulate organic carbon ( $\mu \mathrm{M} \mathrm{C})$ and total particulate nitrogen $(\mu \mathrm{M} N)$ (a), chlorophyll a $(\mu \mathrm{g} / \mathrm{l})$ and particulate organic carbon $(\mu \mathrm{g} / \mathrm{l})(\mathrm{b})$ in the Bay of Bengal.

Fig.6. Distribution of percentage contribution of particulate organic carbon (\% POC) in the offshore $(a, b, c)$, near shore $(d, e, f)$ and shelf/slope $(g, h, i)$ regions during SWM, FIM and SPIM in the Bay of Bengal.

Fig.7. Distribution of $C / N$ ratios in the offshore $(a, b, c)$, near shore $(d, e, f)$ and shelf/slope $(g, h, i)$ regions during SWM, FIM and SPIM in the Bay of Bengal.

Table 1 Result of 2-way ANOVA comparing the seasonal, spatial and depth related variations in the Bay of Bengal. 
Table 1

Result of 2-way ANOVA comparing the seasonal, spatial and depth related variations in the Bay of Bengal.

\begin{tabular}{|c|c|c|c|c|c|c|c|c|c|}
\hline \multirow[t]{3}{*}{ Sampling period } & \multirow[t]{3}{*}{ Variations } & \multicolumn{4}{|c|}{ Chl $a$} & \multicolumn{4}{|c|}{ POC } \\
\hline & & \multicolumn{2}{|c|}{ Offshore region } & \multicolumn{2}{|c|}{ Near shore region } & \multicolumn{2}{|c|}{ Offshore region } & \multicolumn{2}{|c|}{ Near shore region } \\
\hline & & $\mathrm{F}$ & $\mathrm{P}$ & $\mathrm{F}$ & $\mathrm{P}$ & $\mathrm{F}$ & $\mathrm{P}$ & $\mathrm{F}$ & $\mathrm{P}$ \\
\hline & Seasonal & 13.25 & $0.001^{\mathrm{a}}$ & 2.88 & 0.1 & 2.34 & 0.12 & 0.38 & 0.68 \\
\hline \multirow[t]{2}{*}{ SWM } & Spatial & 0.37 & 0.82 & 1.25 & 0.33 & 34.5 & $<0.001^{\mathrm{a}}$ & 0.72 & 0.5 \\
\hline & Depth & 1.94 & 0.15 & 2.16 & 0.08 & 2.13 & 0.07 & 0.87 & 0.55 \\
\hline \multirow[t]{2}{*}{ FIM } & Spatial & 0.52 & 0.71 & 2.02 & 0.16 & 2.87 & $0.04^{\mathrm{a}}$ & 7.15 & $0.002^{\mathrm{a}}$ \\
\hline & Depth & 3.25 & $0.03^{\mathrm{a}}$ & 4.32 & $<0.001^{\mathrm{a}}$ & 9.65 & $<0.001^{\mathrm{a}}$ & 12.9 & $<0.001^{\mathrm{a}}$ \\
\hline \multirow[t]{2}{*}{ SPIM } & Spatial & 4.16 & $0.01^{\mathrm{a}}$ & 1.66 & 0.22 & 5.55 & $0.002^{\mathrm{a}}$ & 2.64 & 0.08 \\
\hline & Depth & 12.23 & $<0.001^{\mathrm{a}}$ & 1.27 & 0.33 & 7.96 & $<0.001^{\mathrm{a}}$ & 6.41 & $0.001^{\mathrm{a}}$ \\
\hline
\end{tabular}

${ }^{a}$ indicates significant difference. 


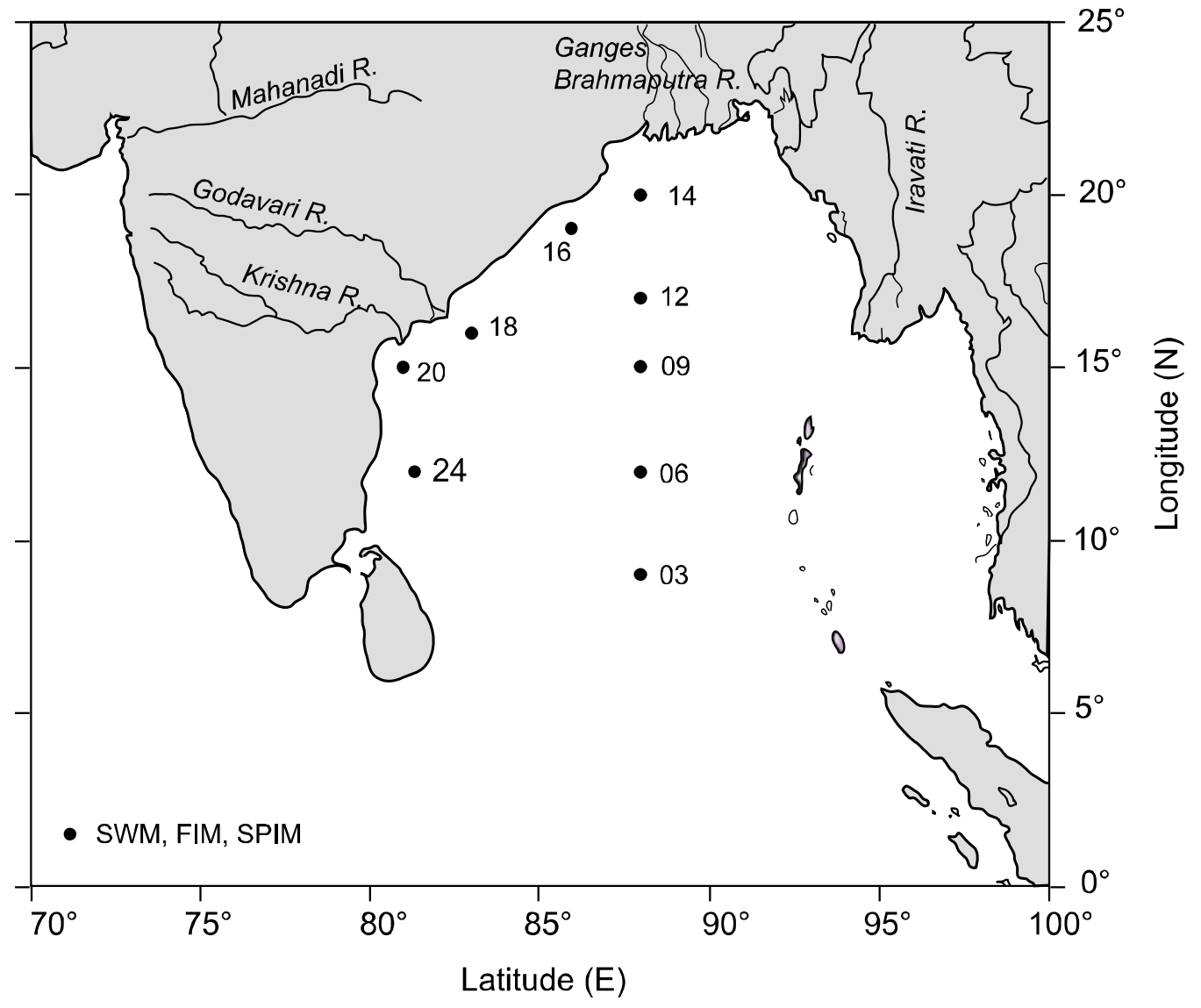

Fig.1. 
(a)

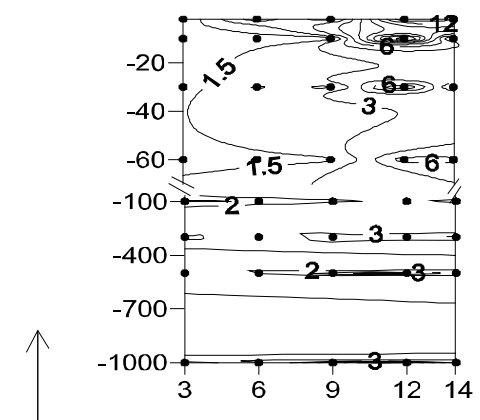

(d)

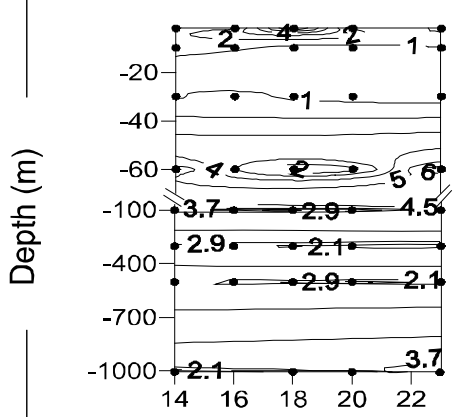

(g)

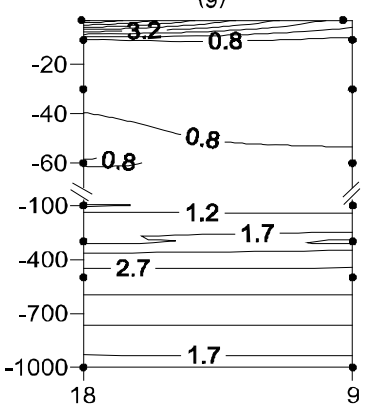

(b)

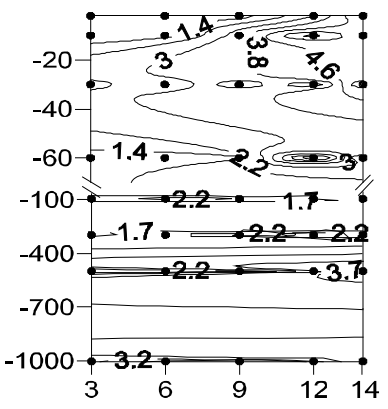

Nearshore region

(e)

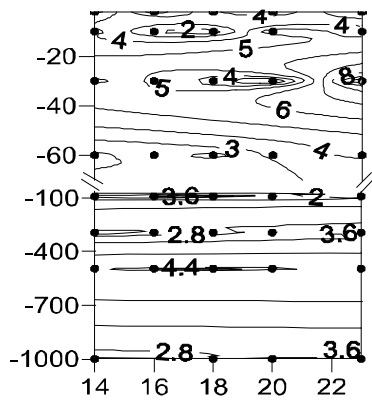

Shelf/Slope W-E

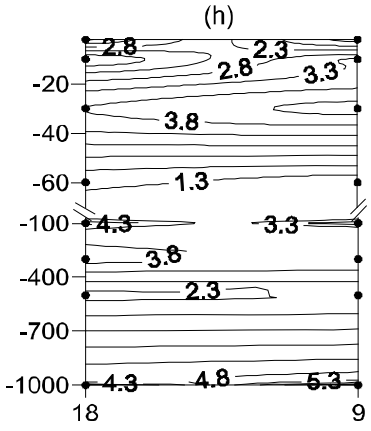

(c)

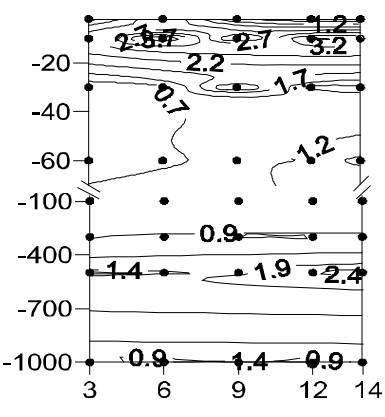

(f)
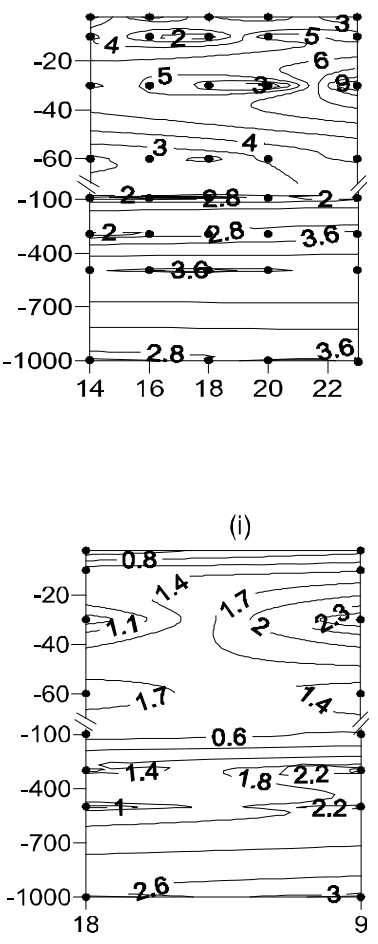

Stations

Fig.2. 
Offshore region

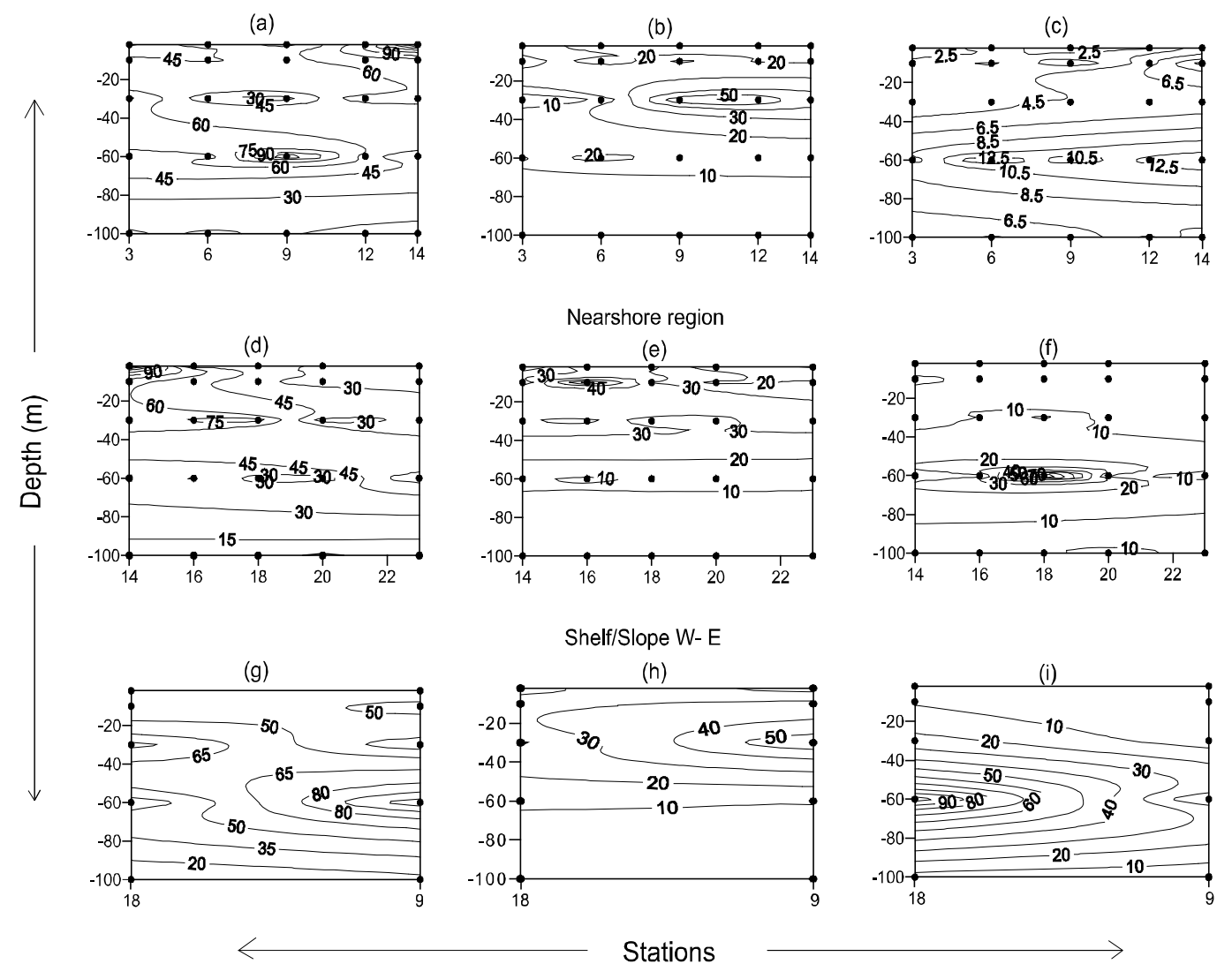

Fig.3. 
(a)

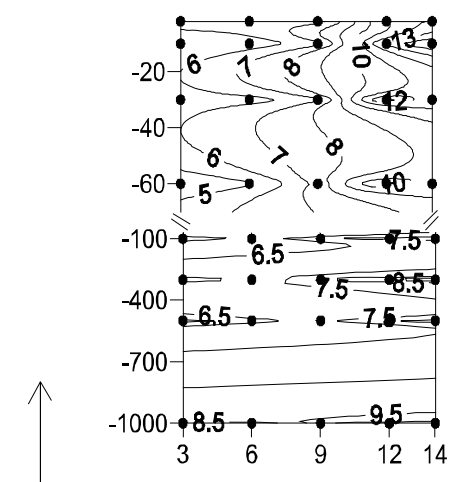

(d)

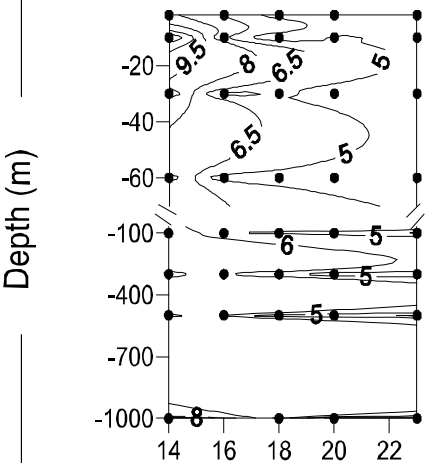

(g)

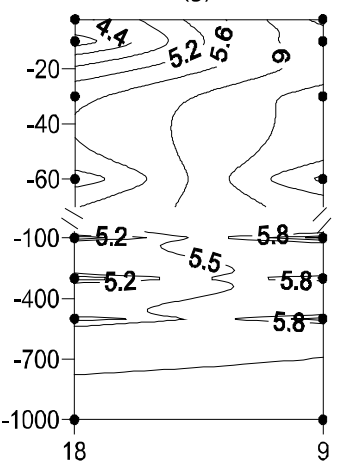

(b)

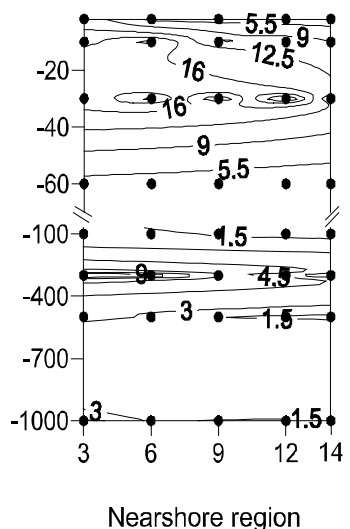

(e)

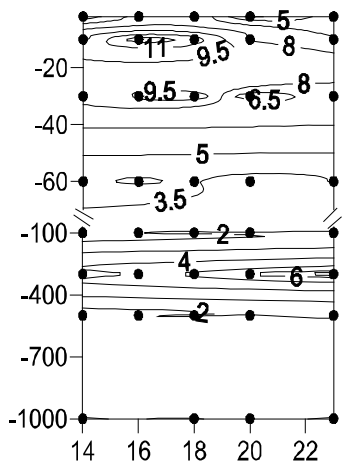

Shelf/Slope W- E

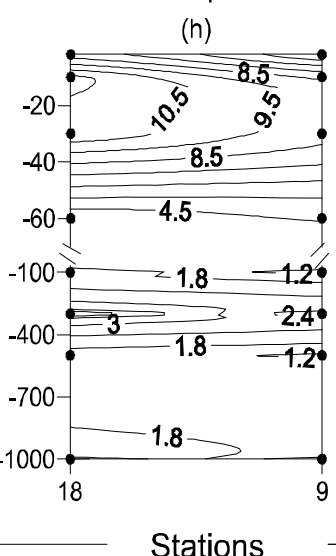

(c)

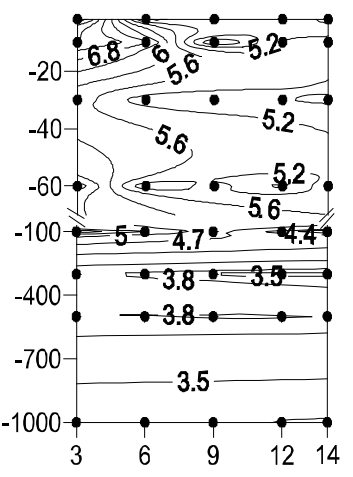

(f)

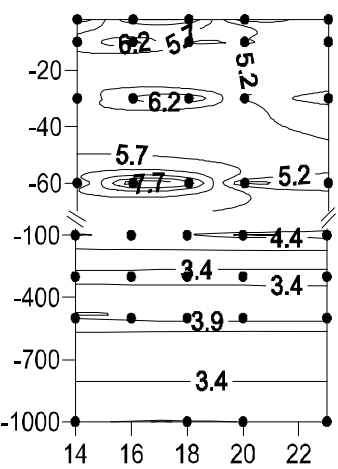

(i)

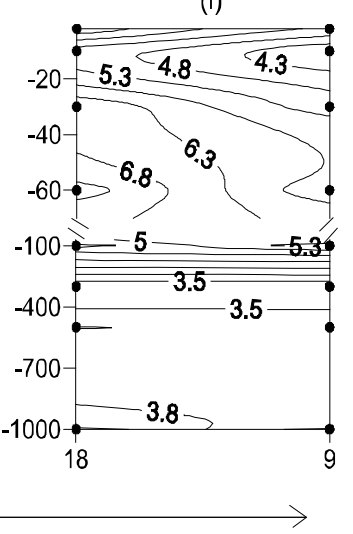

Fig.4. 
(a)

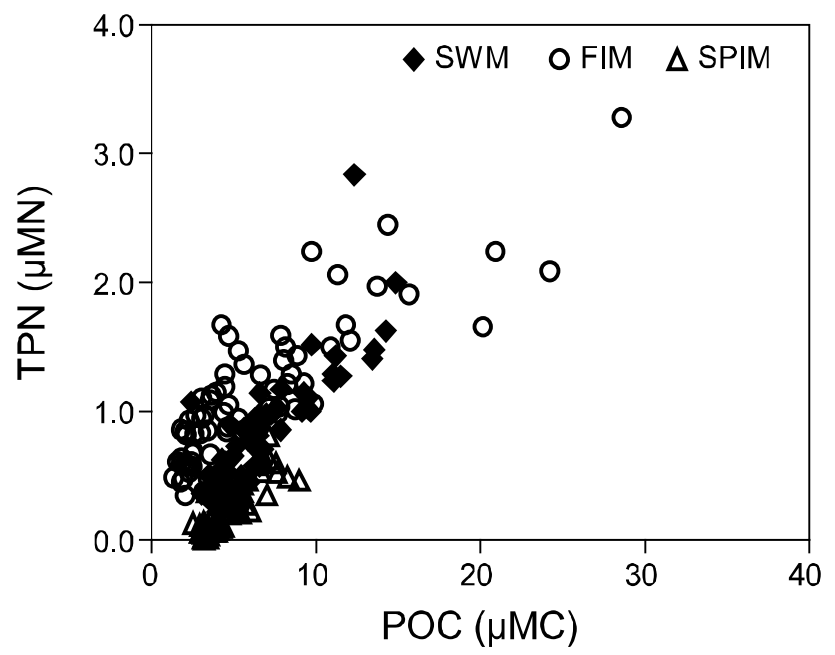

(b)

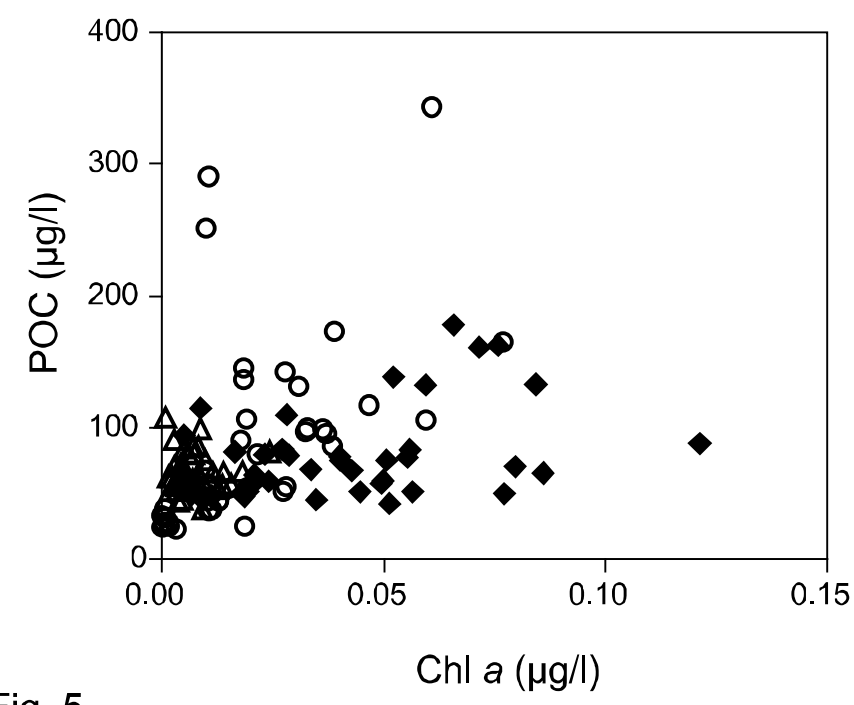

Fig. 5. 
(a)

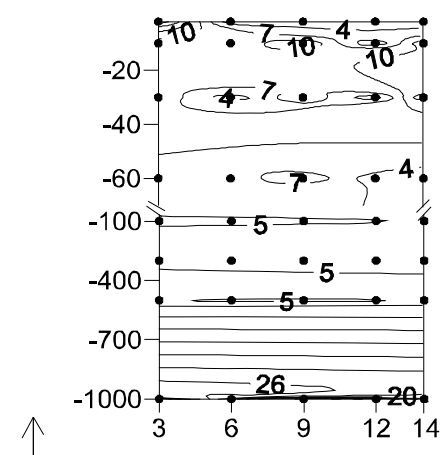

(d)

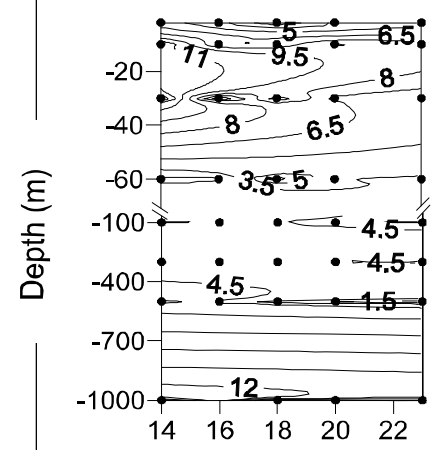

(g)

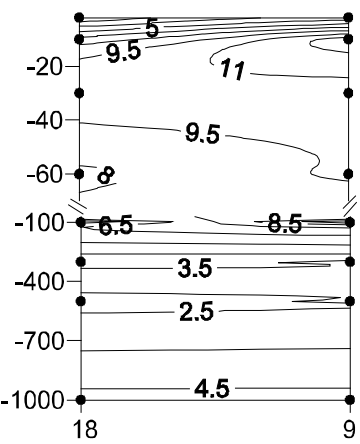

Fig. 6. (b)

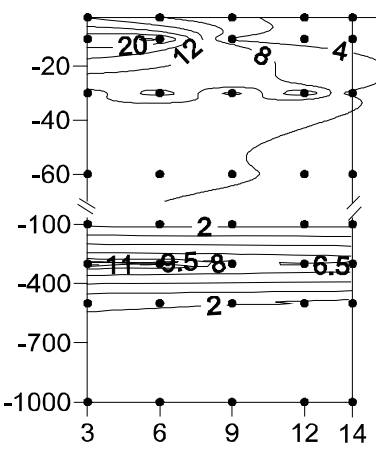

Nearshore region

(e)

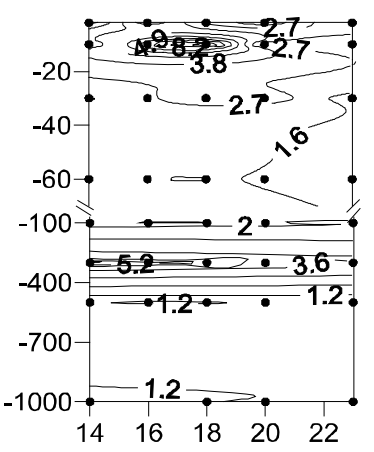

Shelf/Slope W- E

(h)

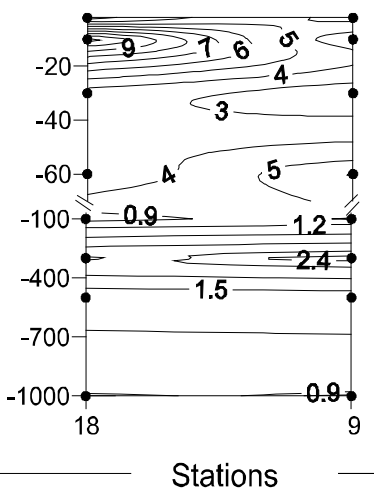

(c)

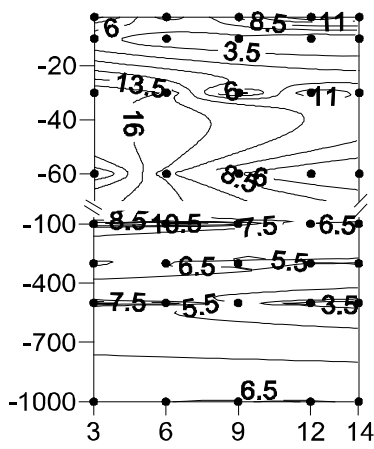

(f)

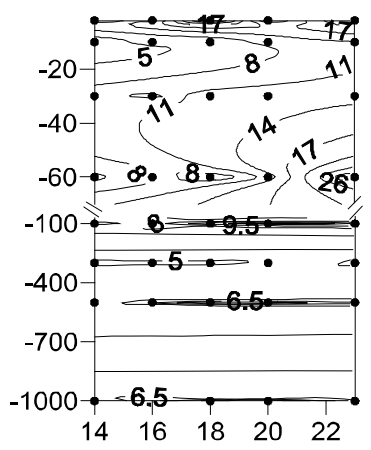

(i)

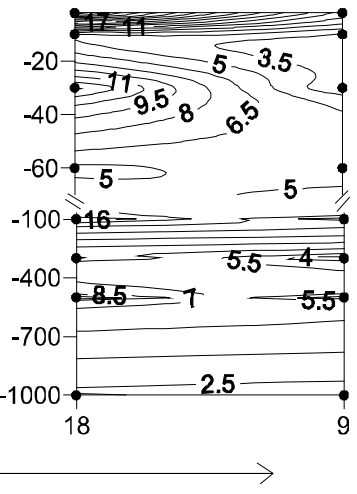


(a)

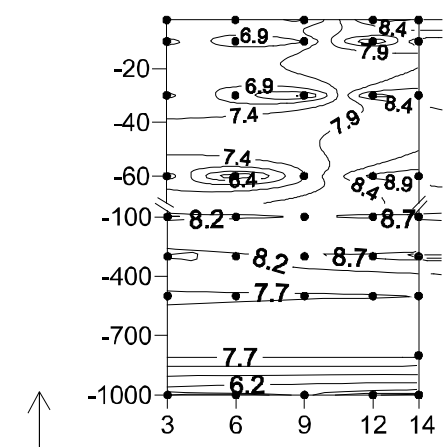

(d)

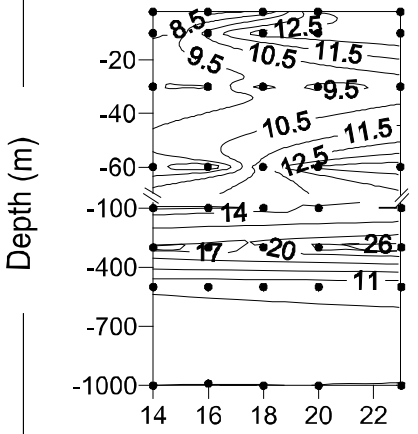

(g)

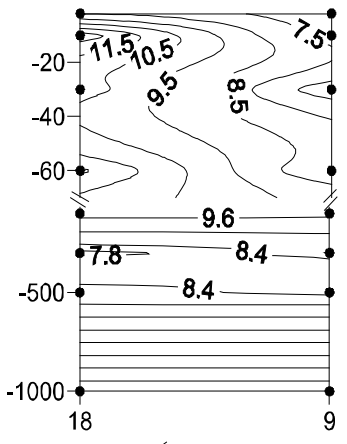

(b)

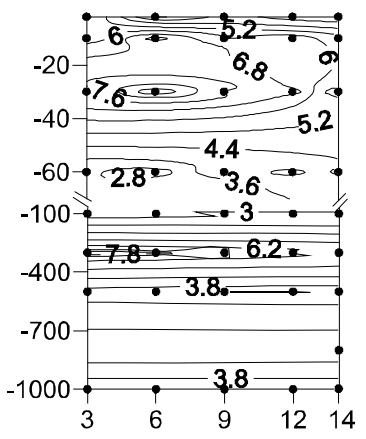

Nearshore region

(e)

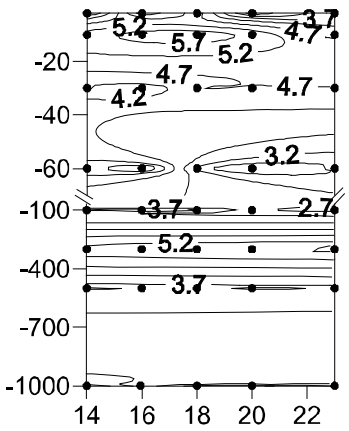

Shelf/Slope W- E

(h)

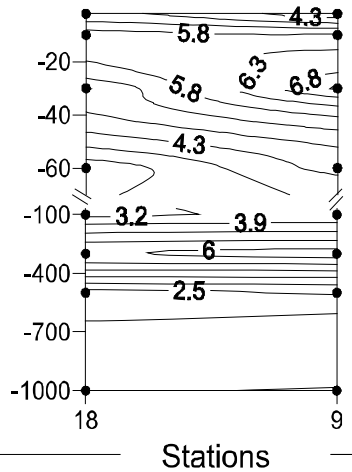

(c)

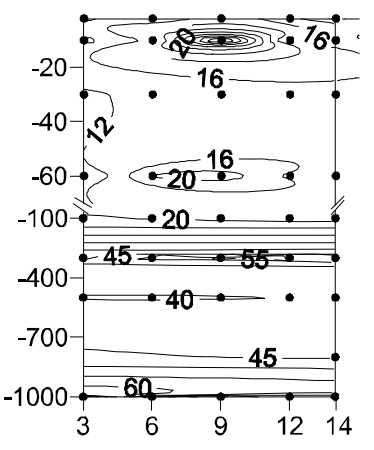

(f)

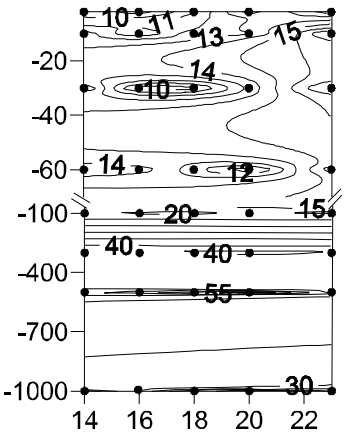

(i)

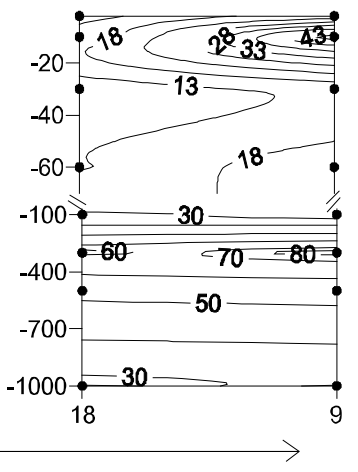

Fig.7. 